\title{
Dentofacial Morphology of Mouth Breathing Children
}

\author{
Patrícia Toledo Monteiro FARIA ${ }^{1}$ \\ Antonio Carlos de Oliveira RUELLAS ${ }^{1,2}$ \\ Mírian Aiko Nakane MATSUMOTO ${ }^{3}$ \\ Wilma T. ANSELMO-LIMA ${ }^{4}$ \\ Fabiana C. PEREIRA ${ }^{4}$ \\ ${ }^{1}$ Specialization Course in Orthodontics and Facial Orthopedics, EFOA, Alfenas, MG, Brazil \\ ${ }^{2}$ Department of Orthodontics, Faculty of Dentistry, Federal University of Rio de Janeiro, Rio de Janeiro, RJ, Brazil \\ ${ }^{3}$ Discipline of Orthodontics, Faculty of Dentistry of Ribeirão Preto, University of São Paulo, Ribeirão Preto, SP, Brazil \\ ${ }^{4}$ Department of Otorhinolaryngologics, Faculty of Medicine of Ribeirão Preto, University of São Paulo, \\ Ribeirão Preto, SP, Brazil
}

\begin{abstract}
The relationship between dentofacial morphology and respiration has been debated and investigated from various approaches. The aim of this study was to verify the skeletal and dental relationship of mouth and nose breathing children. Thirty-five children, 7 to 10 years of age, were submitted to orthodontic and otorhinolaryngologic evaluations and were separated into 2 groups: 15 nose breathers and 20 mouth breathers. Each subject underwent a cephalometric radiograph analysis. Statistical analysis (Mann-Whitney U test) indicated that changed mode of breathing was associated with 1) maxillo-mandibular retrusion in relation to the cranial base in the mouth breathers; 2) the SNGoGn and NSGn angles were greater in the mouth breathing group; 3) incisor inclination in both jaws and the interincisal angle were not different between groups. There was no statistically significant difference in the maxillary and mandibular molar heights between the nose breathers and mouth breathers.
\end{abstract}

Key Words: mouth breathing, malocclusion, cephalometrics.

\section{INTRODUCTION}

Nose breathing associated with the normal functions of chewing and swallowing and posture of tongue and lips provides correct muscular action stimulating adequate facial growth and bone development (1). Dentofacial morphology can be altered by dysfunctions, such as nasorespiratory obstruction depending on the magnitude, duration and time of occurrence (2).

When nose breathing is disrupted by adenoid and tonsil hypertrophy, rhinitis, nasal septum deviation, among others $(3,4)$, there is a prevalence of mouth breathing. Mouth breathing may lead to postural changes such as lowered position of the mandible, raised position of the head, low posture of the hyoid bone and anterior inferior position of the tongue $(1,2,5)$. It has also been shown that such postural changes may be related to specific dentofacial characteristcs and morphological changes (6).

According to Paul and Nanda (7), there is much evidence that mouth breathing produces deformities of the jaws, inadequate position or shape of the alveolar process and malocclusion and results in the development of "adenoidal facies" or "long face syndrome" $(8,9)$. The aim of the present investigation was to verify skeletal and dental relationships of mouth and nose breathing children.

\section{MATERIAL AND METHODS}

Thirty-five children of both sexes ranging in age from 7 to 10 years were selected from the Orthodontic Service of the Faculty of Dentistry of Ribeirão Preto, USP. The children were submitted to otorhinolaryngological and dental evaluations that consisted of anamnese, specific physical examination, nasofibroscopy, cavum radiographs and cephalometrical analysis. The children were evaluated in the Otorhinolaryngology Department of the Faculty of Medicine of Ribeirão Preto, USP and they were further separated into 2 
groups: nose breathers $(\mathrm{N}=15)$ and mouth breathers $(\mathrm{N}$ $=20$ ) according to the results of clinical, physical and nasofibroscopic examinations and cavum radiographs based on methods proposed by Cohen and Konak (10).

Nose breathers met the following criteria: 1) light or no alteration in the radiographic exam; 2) nasopharynx obstruction less than $30 \%$ detected by nasofibroscopy exam; 3) no history of orthodontic treatment. Mouth breathers demonstrated: 1) evident alteration in the radiographic exam; 2) nasopharynx obstruction greater than $60 \%$ (some patients presented $100 \%$ obstruction that could be associated to allergic rhinitis, hypertrophy of palatal tonsil, among others); 3) no history of orthodontic treatment.

Standard lateral cephalometric radiographs were obtained to evaluate the skeletal and dental characteristics of both groups. The cephalometric radiographs were traced on 0.002 inch acetate paper and dental and skeletal anatomic landmarks were located and used for the angular and linear measurements (Figure 1).

The data were submitted to statistical analysis using the GMC program, 7.7 version. The non-parametric Mann-Whitney U test was used. The level of significance was set at $\mathrm{p}<0.01$.

\section{RESULTS AND DISCUSSION}

The statistical analysis indicated that there was a statistically significant difference $(p<0.05)$ for SNA and SNB angles. The maxilla and mandible were more retrognathic in the mouth-breathing group (Table 1). These results are in agreement with the literature $(3,11,12)$. The maxillae were more retrognathic owing to upper airway obstruction resulting from the hypoplasia of the maxillary sinus and narrowing of the nasal cavities. Trask et al. (13), Martins (14) and SantosPinto et al. (15) verified that the mandible was retrognathic in relation to the cranial base. The SNB angle was less in the allergic mouth breathers and the SNA angle did not present alterations. Ricketts (16) reported that the SNB angle was located more posteriorly in relation to the cranial base because the forward and downward tongue posture was even more marked when the nasopharynx was filled with adenoid tissue. Therefore, it was speculated that respiration was one factor predisposing to malocclusion of teeth due to the influence of tongue posturing and possibly even the positioning of the mandible, which was maintained downward and backward in the growth phase.

Figure 1. Tracing illustrating anatomic landmarks, points, lines and angles used in this study.

To evaluate the antero-posterior skeletal relationships:

SNA: angle determined by the intersection of SN and NA lines and expresses the degree of protrusion and retrusion of the maxilla in relation to the cranial base.

SNB: angle determined by the intersection of $\mathrm{SN}$ and $\mathrm{NB}$ lines and establishes the degree of protrusion and retrusion of the mandible in relation to cranial base.

ANB: angle formed by the intersection of NA and NB lines which measures anteroposterior relation of the maxilla and the mandible.

To evaluate the vertical skeletal relationships:

SNGoGn: angle measuring the inclination of the mandibular plane (GoGn) in relation to the anterior base of the cranium (SN).

NSGn: angle measuring the direction of the facial growth.

To evaluate dental relationships:

1.SN: maxillary incisor inclination to the sella-nasion plane which measures the proclination or retroclination of the maxillary incisors.

IMPA: mandibular incisor inclination to mandibular plane which measures the proclination or retroclination of the mandibular incisors.

1.1 (interincisal angle): the angle formed between the long axes of the maxillary and mandibular incisors.

Msc-palatal plane: linear measure which represents the height of the maxillary first molar in relation to the palatal plane.

Mic-mandibular plane: linear measure which represents the height of mandibular first molar in relation to mandibular plane.

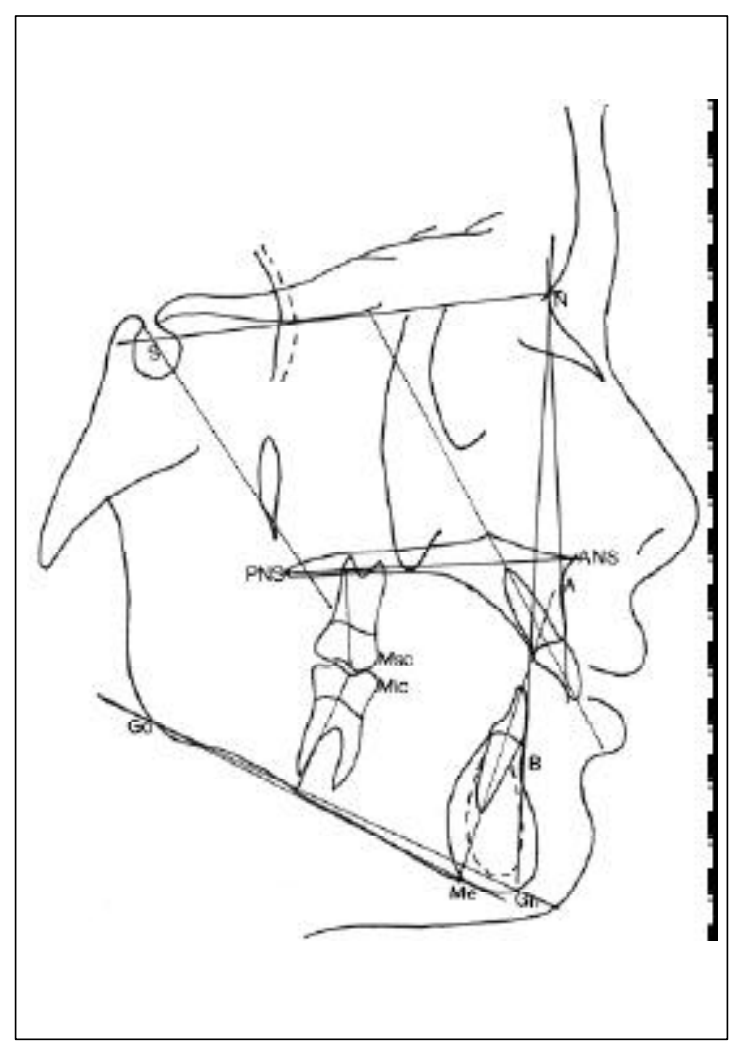


According to the results obtained in this study, mouth breathing interfered in the anteroposterior position of the maxilla, because of a reduction of air flow in the nasal cavity. This leads to nasal and paranasal hypoplasia and reduction of tongue pressure against the palate where deviation in the vertical growth, as the mandible remains downward and backward in relation to the cranial base, can occur.

The ANB angle was not statistically different between groups (Table 1), which is in agreement with Bresolin et al. (11) who studied both nose and mouth breathers with allergic rhinitis.

Angular measurements of vertical skeletal relationships were significantly different between groups. The angular relationship of the sella-nasion to the mandibular plane (SNGoGn) was larger in the mouth breathing group (Table 1). The NSGn angle was significantly larger in the mouth breathing group (Table 1). In children with nasal obstruction, there was a dorsal rotation of the mandible. Linder-Aronson et al. (9) and Solow et al. (17) reported that nasal obstruction can also alter the airway and, subsequently, facial growth. The mouth breathers had longer faces and their mandibles had more obtuse gonial angles, resulting in a vertical growth pattern $(8,9,12,15,18,19)$.

There were no statistically significant differences for maxillary molar height, mandibular molar height, IMPA, 1.SN and 1.1 between groups (Table 2). It can be supposed that, as the mandible rotated downward and backward in the mouth breathers, the fulcrum was located in the region of the permanent first molar. In relation to the height of both maxillary and mandibular molars, Santos-Pinto (12) found the same results. However, Subtelny (3) and Rubin (19) reported that mouth breathers have more developed vertical alveolar process in the posterior region of the dental arches.

The results found in the literature about the inclination of the maxillary and mandibular incisors (1.SN, IMPA and 1.1) are controversial because McNamara Jr. (1) and Paul and Nanda (7) concluded that maxillary incisors were protruded in the mouth breathers, justified by interposition of the hypertonic lower lip between maxillary and mandibular incisors provoking labioversion of the maxillary incisors. However, Subtelny (3) and Solow et al. (17) saliented that maxillary incisors are found retroclinate in these patients in relation to the S-N line and Tarvonen and Koski (20) reported that the mandibular incisors pre-

Table 1. Comparison of the skeletal pattern of nose and mouth breathing children.

\begin{tabular}{lccccc}
\hline & SNA & SNB & ANB & SNGoGn & SNGn \\
\hline Nose breathers & $83.13 \pm 2.26$ & $78.43 \pm 2.53$ & $4.70 \pm 2.49$ & $33.87 \pm 4.01$ & $67.8 \pm 2.76$ \\
Mouth breathers & $80.60 \pm 3.53$ & $75.80 \pm 3.86$ & $4.80 \pm 2.91$ & $37.60 \pm 4.28$ & $70.4 \pm 4.68$ \\
P(HO) $(\%)$ & 1.86 & 2.10 & 48.67 & 0.98 & 4.47 \\
Z value & 2.0833 & 2.0333 & 0.0333 & -2.3333 & $* 1.7000$ \\
Significance & $*$ & $*$ & n.s & $*$ \\
\hline
\end{tabular}

Data are reported as means \pm SD. See Figure 1 for explanation of abbreviations.

$* \mathrm{p}<0.05 ; * * \mathrm{p}<0.01 ; \mathrm{ns}=$ not significant (Mann- Whitney U test).

Table 2. Comparison of the dental pattern of nose and mouth breathing children.

\begin{tabular}{lccccc}
\hline & Msc-PP & Mic-Mp & IMPA & 1.SN & 1.1 \\
\hline Nose breathers & $18.87 \pm 2.26$ & $26.60 \pm 1.50$ & $94.07 \pm 5.30$ & $104.40 \pm 5.85$ & $126.40 \pm 7.01$ \\
Mouth breathers & $18.72 \pm 2.63$ & $27.27 \pm 1.97$ & $92.00 \pm 5.92$ & $102.87 \pm 6.64$ & $128.70 \pm 7.95$ \\
P(HO) $(\%)$ & 48.01 & 12.17 & 20.71 & 35.07 & 27.43 \\
Z value & 0.0500 & -1.1667 & 0.8167 & 0.3833 & -0.6000 \\
\hline
\end{tabular}

Data are reported as mean \pm SD. See Figure 1 for explanation of abbreviations. There were no statistical differences between the two groups (Mann-Whitney U test). 
sented retroclinate in relation to the mandibular plane in patients with hypertrophic adenoid.

Because upper airway obstruction is an obstacle to normal dentofacial development, mouth breathing children deserve prompt attention before growth has proceeded irreversibly.

\section{RESUMO}

Faria PTM, Ruellas ACO, Matsumoto MAN, Anselmo-Lima WT, FC Pereira. Morfologia dentofacial de crianças respiradoras bucais. Braz Dent J 2002;13(2):129-132

A relação entre respiração e morfologia dento-facial tem sido discutida e investigada sob vários aspectos. O objetivo deste estudo foi verificar a morfologia dentária e esquelética de crianças respiradoras nasais e bucais. Trinta e cinco crianças, com idade entre 7 e 10 anos, foram submetidas às avaliações ortodônticas e otorrinolaringológicas e foram, então, divididas em 2 grupos: um grupo contendo quinze crianças respiradoras nasais e outro, com vinte respiradores bucais. Cada uma das crianças foi submetida à análise cefalométrica. $\mathrm{O}$ tratamento estatístico indicou que a respiração alterada está associada com: 1) retrusão maxilo-mandibular em relação à base do crânio, nos pacientes respiradores bucais; 2) os ângulos SNGoGn e NSGn foram maiores no grupo de respiradores bucais; 3 ) a inclinação axial dos incisivos superiores e inferiores e o ângulo interincisal não foram diferentes entre os grupos. Não houve diferença estatisticamente significante nas alturas molares superiores e inferiores entre os dois grupos avaliados.

Unitermos: respiração bucal, maloclusão, cefalometria.

\section{ACKNOWLEDGMENTS}

The authors would like to express their appreciation to Dr. Maria da Glória Chiarello de Mattos, for performing the statistical analysis of this study.

\section{REFERENCES}

1. McNamara Jr JA. Influence of respiratory pattern on craniofacial growth. Angle Orthod 1981;51:269-300.

2. O'Ryan FS, Gallagher DM, LaBanc JP, Epker BN. The relation between nasorespiratory function and dentofacial morphology. A review. Am J Orthod 1982;82:403-410.
3. Subtelny JD. Oral respiration: facial maldevelopment and corrective dentofacial orthopedics. Angle Orthod 1980;50:147-164.

4. Woodside DG, Linder-Aronson S, Ludströen A, McWilliam J. Mandibular and maxillary growth after changed mode of breathing. Am J Orthod 1991;100:1-17.

5. Tourne LPM, Schweiger J. Immediate postural responses to total nasal obstruction. Am J Orthod Dentofac Orthop 1996;110:606611

6. Warren DW. Effect of airway obstruction upon facial growth. Otolar Clin N Am 1990;23:699-712.

7. Paul JL, Nanda RS. Effect of mouthbreathing on dental occlusion. Angle Orthod 1973;43:201-206

8. Weimert T. Airway obstruction in orthodontic practice. J Clin Orthod 1986;20:96-105.

9. Linder-Aronson S, Woodside DG, Hellsing E. Normalization of incisor position after adenoidectomy. Am J Orthod 1993;103:412427

10. Cohen D, Konak S. The evaluation of radiograph of the nasopharynx. Clin Otolaringol 1985;10:73-78.

11. Bresolin D, Shapiro PA, Shapiro GG, Chapko MK, Dassel S. Mouth breathing in allergic children: Its relationship to dentofacial development. Am J Orthod 1983;83:334-339.

12. Santos-Pinto A. Alterações nasofaringeanas e craniofaciais em pacientes com adenóide hipertrófica: estudo cefalométrico. [Master's thesis]. Rio de Janeiro: Faculdade de Odontologia, Universidade Federal do Rio de Janeiro; 1984. 72 p.

13. Trask GM, Shapiro GG, Shapiro PA. The effects of perennial allergic rhinitis on dental and skeletal development: A comparison of sibling pairs. Am J Orthod Dentofac Orthop 1987;92:286293

14. Martins JCR. Influência da hipertrofia amigdaliana nas más oclusões de classe I e classe II divisão 1 de angle. Estudo cefalométrico. Ortodontia 1989;22:4-11.

15. Santos-Pinto CCM, Henriques JFC, Pinzan A, Freitas MR, Santos-Pinto A. Estudo radiográfico e de modelos para a avaliação de alterações dentofaciais em função da reclusão do espaço nasofaringeano em jovens brasileiros, leucodermas de 8 a 14 anos. Ortodontia 1993;26:57-74.

16. Ricketts RM. Forum on the tonsil and adenoid problem in orthodontics: respiratory obstruction syndrome. Am J Orthod 1968;54:485-514.

17. Solow B, Siersbaek-Nielsen S, Greve G. Airway adequacy, head posture and craniofacial morphology. Am J Orthod 1984;86:214223.

18. Harvold EP, Tomer BS, Vargervik K, Chierici G. Primate experiments on oral respiration. Am J Orthod 1981;79:359-372.

19. Rubin RM. The effects of nasal airway obstruction. J Pedod 1983;8:3-27.

20. Tarvonen PL, Koski K. Craniofacial skeleton of 7-year-old children with enlarged adenoids. Am J Orthod Dentofacial Orthop 1987;91:300-304. 